\title{
Glassy Cell Carcinoma
}

National Cancer Institute

\section{Source}

National Cancer Institute. Glassy Cell Carcinoma. NCI Thesaurus. Code C65159.

A malignant epithelial neoplasm composed of atypical cells with glassy cytoplasm. 